\title{
THE RESTRICTIVE BUSINESS PRACTICES CLAUSE IN UNITED STATES TREATIES: AN ANTITRUST TRANQUILIZER FOR INTERNATIONAL TRADE
}

\author{
JAMES T: HAIGHTi்
}

THE Restrictive Business Practices Clause is an important but little used paragraph which first appeared in the United States Treaty of Friendship, Commerce, and Navigation with Italy in 1948. This clause calls for intergovernmental consultation and action with respect to restrictive business practices which may have harmful effects upon commerce between the two countries. The provision is an effective part of eight treaties now in force.

How did this provision get into these treaties? Why is it there? How has it been used? What value has it in the future? These questions have never been fully or officially answered by either the Department of State or the Department of Justice.

\section{Postwar Anticartel Activities}

As Allied guns were booming on the Brittany peninsula in 1944, President Franklin D. Roosevelt took time from his military responsibilities to address a letter to Cordell Hull, Secretary of State. The President mentioned the need to eradicate the German cartel structure after the war and then went on to declare that all "cartel practices" which might restrict the free flow of goods in foreign commerce would have to be curbed, perhaps by joint action of the United Nations. He concluded,

I hope that you will keep your eye on this whole subject of international cartels because we are approaching the time when discussions will almost certainly arise between us and other nations. ${ }^{1}$

The Secretary of State replied, indicating (not unexpectedly) agreement with the points outlined by F.D.R. and noting that an interdepartmental committee had been established to keep a continuing watch over cartel matters. Mr. Hull alerted the top-flight Executive Committee on Economic Foreign Policy to be ready on short notice with definitive policy proposals. ${ }^{2}$ The Executive Branch had begun its postwar effort to clarify its responsibility in applying America's antitrust policies to restraints on international commerce. During the next decade and a half, United States efforts would be directed, in part, to multilateral arrangements relating to restraints in international

$†$ Member of the District of Columbia, Ohio and Wisconsin Bars; Attorney, Akron, Ohio.

1. Letter From the President to the Secretary of State, Sept. 6, 1944, in 11 Dep'T State Bull. 254 (1944).

2. Letter From the Secretary of State to the President, Sept. 11, 1944, in 11 DEP'T State Bull. 292-93 (1944). 
trade. The United Nations did not itself take up the cartel question at once but it did sponsor publication of a research paper drafted by the old League of Nations Secretariat. This paper concluded that while international cartels might be useful in some circumstances, "intergovernmental agreements may be necessary to regulate them." 3 Meanwhile, during the Anglo-American loan negotiations in 1945, the United States had proposed that the parties conclude a multilateral agreement under which the nations would pledge themselves to take effective steps to prevent their nationals from engaging in price fixing, market sharing, or other practices restraining trade. A British counterproposal suggested that a consultative body be formed to which any country could report its fears that an international cartel was acting in restraint of trade. ${ }^{4}$ When the International Trade Organization (ITO) was proposed by the United States under the 1948 Havana Charter, it was to include a Commission on Business Practices. The commission's main function would have been to:

1. Inquire into activities on the part of private commercial enterprises which have the effect or purpose of restraining international trade, restricting access to international markets, or of fostering monopolistic controls in international trade. ${ }^{5}$

The ITO never got off the ground, because the United States Senate refused to ratify it. However the germ of the charter's commission idea was carried into the United States commercial treaty program.

\section{The Restrictive Business Practices Clause}

President Truman presented to the United States Senate on April 14, 1948 a Treaty of Friendship, Commerce, and Navigation with the new Italian Republic. The treaty had been signed at Rome on February 2, 1948, replacing a treaty signed at Florence in 1871.

The Restrictive Business Practices Clause appeared in this treaty for the first time. It reads :

The two High Contracting Parties agree that business practices which restrain competition, limit access to markets or foster monopolistic control, and which are engaged in or made effective by one or more private or public commercial enterprises or by combination, agreement or other arrangement among public or private commercial enterprises may have harmful effects upon the commerce between their respective territories. Accordingly, each High Contracting Party agrees upon the request of the other High Contracting Party to consult with respect to any such practices and to take such measures as it deems appropriate with a view to eliminating such harmful effects. ${ }^{6}$

3. United Nations, International Cartels 48-52 (1947).

4. N.Y. Times, Oct. 9, 1945, p. 2, col. 8.

5. Havana Charter for an International Trade Organization, March 24, 1948, U.S. Dep't State Pub. No. 3206, Commercial Policy Series 114 (1948).

6. Treaty With Italy on Friendship, Commerce, and Navigation, Feb. 2, 1948, art. XVIII, pará. 3, 63 Stat. 2255, T.I.A.S. No. 1965 (effective July 26, 1949). 
In its report to the President, the State Department vaguely described this new provision as "arising directly from recent developments in international economic relations." It added, equally vaguely,

The provisions relating to exchange controls, state trading, and restrictive trade practices have been formulated in the light of recent experience with such economic devices, and it is believed that for the most part these articles will eliminate the most discriminatory features and thereby lessen possible harmful effects upon American business activity. ${ }^{7}$

Explaining the clause to the Foreign Relations Committee of the Senate, the State Department spokesman advised that it was "directed at the cartel or monopoly situation." Its purpose was "to provide a mechanism for doing something about it."8 The State Department has, through a variety of intergovernmental mechanisms, continued its attempts to eliminate both public and private restrictions in international trade. Bilateral treaties under the ECA program with Western European countries have contained provisions attacking the problem. ${ }^{9}$ The decartelization program in Western Germany and in Japan was pressed forward. ${ }^{10}$ But the commercial treaty program remains an important tool.

In furtherance of this program, twenty commercial treaties have been negotiated by the United States since the end of World War II, ${ }^{11}$ of which thirteen have come into force. ${ }^{12}$ The Restrictive Business Practices Clause was incorporated substantially without change in eight of them. In addition

7. Report of the Secretary of State to the President, April 13, 1948, printed in Message from the President transmitting the Treaty to the Senate, S. Exrc. E, 80th Cong., 2d Sess. 3 (1948). The report also stated that the Restrictive Trade Practices Clause was similar to the article proposed by the United States for the charter of the ITO.

8. Hearing before a Subcommittee of the Senate Committee on Foreign Relations on a proposed Treaty of Friendship, Commerce, and Navigation between the U.S. and the Italian Republic, 80th Cong., 2d Sess. 21 (1948).

9. E.g., Economic Cooperation Agreement with the United Kingdom, July 6, 1948, art. II, para. 3, 62 Stat. 2596, T.I.A.S. No. 1795.

10. See Dep't of State Press Release, Dec. 1, 1949, 21 Dep't State Bulc. 910 (1949). Other activities are described in the Report of the Dep't of State to the Subconsmitree on Monopoly of the Senate Select Committee on Smalc Business, Foreign Legiszation Concerning Monopoly and Cartel Practices, 82d Cong., 2d Sess. 171-78 (1952).

11. "Commercial treaties" in this sense includes the standard treaties of friendship, commerce, and navigation; treaties of amity, economic relations, and consular rights; conventions of establishment; and similar treaties dealing with general economic relations, the encouragement of commerce, and the protection of persons and investments. For a general description of the program, see Commercial Treaty Program of the United States, U.S. Dep't of State, Pub. No. 6565, Comamercial Policy Series 163 (1958).

12. After negotiation and initial signature, a treaty must be ratified by the parties. In the United States, this requires the advice and consent of the Senate, prior to ratification by the President. Only after ratifications are exchanged does a treaty come into force. This process is described fully in 2 Hyde, International Law 1429-52 (1951). 
to the treaty with Italy, the clause is part of the following Treaties of Friendship, Commerce, and Navigation : Ireland, ${ }^{13}$ Israel, ${ }^{14}$ Greece, ${ }^{15}$ Japan, ${ }^{16}$ Germany, ${ }^{17}$ Korea, ${ }^{18}$ and Nicaragua. ${ }^{18}$

The clause is not contained in the commercial treaties with Nationalist China, ${ }^{20}$ Ethiopia, ${ }^{21}$ Iran, ${ }^{22}$ the Netherlands, ${ }^{23}$ and Muscat and Oman. ${ }^{24}$ It is missing from the Chinese treaty because the clause was only a gleam in its author's eye in 1946. The Ethiopian, Iranian, and Muscat and Oman treaties are abridged versions of the standard commercial treaty, because of the relatively undeveloped status of these countries. ${ }^{25}$ The absence of the clause in the treaty with the Netherlands has not been officially explained. However, it is known that the Netherlands Government flatly refused to accept the clause.

13. Treaty With Ireland of Friendship, Commerce, and Navigation, Jan. 21, 1950, art. XV, para. 1, [1950] 1 U.S.T. \& O.I.A. 785, T.I.A.S. No. 2155 (effective Sept. 14, 1950).

14. Treaty With Israel of Friendship, Commerce, and Navigation, Aug. 23, 1951, art. XVII, para. 1, [1954] 1 U.S.T. \& O.I.A. 550, T.I.A.S. No. 2948 (effective Apri1 3, 1954).

15. Treaty With Greece of Friendship, Commerce, and Navigation, Aug. 3, 1951, art. XIV, para. 1, [1954] 2 U.S.T. \& O.I.A. 1829, T.I.A.S. No. 3057 (effective Oct. $13,1954)$.

16. Treaty With Japan of Friendship, Commerce, and Navigation, April 2, 1953, art. XVIII, para. 1, [1953] 2 U.S.T. \& O.I.A. 2063, T.I.A.S. No. 2863 (effective Oct. $30,1953)$.

17. Treaty With Germany of Friendship, Commerce, and Navigation, Oct. 29, 1954, art. XVIII, para. 1, [1956] 2 U.S.T. \& O.I.A. 1839, T.I.A.S. No. 3593 (effective July 14, 1956). This treaty modified the final clause of standard Restrictive Business Practices Clause by adding the italicized language:

Accordingly, each Government agrees upon the request of the other Government to consult with respect to any such practices and to take such measures, not precluded by its legislation, as it deems appropriate with a view to eliminating such harmful effect.

18. Treaty With Korea of Friendship, Commerce, and Navigation, Nov. 28, 1956, art. XVIII, para. 1, [1957] 2 U.S.T. \& O.I.A. 2217, T.I.A.S. No. 3947 (effective Nov. 7, 1957).

19. Treaty With Nicaragua of Friendship, Commerce, and Navigation, Jan. 21, 1956, art. XVIII, para. 1, [1958] 1 U.S.T. \& O.I.A. 449, T.I.A.S. No. 4024 (effective May 24,1958 ).

20. Treaty With The Republic of China of Friendship, Commerce, and Navigation, Nov. 4, 1946, 63 Stat. 1299, T.I.A.S. No. 1871 (effective Nov. 30, 1948).

21. Treaty With Ethiopia of Amity and Economic Relations, Sept. 7, 1951, [1953] 2 U.S.T. \& O.I.A. 2134, T.I.A.S. No. 2864 (effective Oct. 8, 1953).

22. Treaty With Iran of Amity, Economic Relations, and Consular Rights, Aug. 15, 1955, [1957] 1 U.S.T. \& O.I.A. 899, T.I.A.S. No. 3853 (effective June 16, 1957).

23. Treaty With The Netherlands of Friendship, Commerce, and Navigation, March 27, 1956, [1957] 2 U.S.T. \& O.I.A. 2043, T.I.A.S. No. 3942 (effective Dec. 5, 1957).

24. Treaty With the Sultan of Muscat and Oman of Amity, Economic Relations, and Consular Rights, Dec. 20, 1958, T.I.A.S. No. 4530 (effective June 11, 1960).

25. Report of the Acting Secretary of State to the President, February 19, 1959, printed in S. Exec. A., 86th Cong., 1st Sess. 2 (1959) ; S. Exec. Rep. No. 1, 86th Cong., 1st Sess. 4 (1959). Abridged versions are further explained in Walker, Modern Treaties of Friendship, Commerce and Navigation, 42 MinN. L. REv. 805, 807 (1958). 
While negotiations were under way, the Justice Department was prosecuting Netherlands companies-N. V. Philips, for one-in antitrust litigation. The Netherlands Government, incensed at these proceedings, stoutly refused to undertake any commitment that might involve them in giving effect to United States antitrust laws in the Netherlands.

Not many private organizations take the trouble to comment on proposed treaties. One organization that frequently does is the National Foreign Trade Council (NFTC). When half a dozen treaties were pending before the Senate in 1952, the NFTC questioned the desirability of including the Restrictive Business Practices Clause in four of them.

In a statement to the Senate Foreign Relations Committee, the NFTC declared that while it had originally viewed the clause as being merely a condemnation of practices contrary to the letter and spirit of American antitrust law, it subsequently revised its view in the light of the constitutional declaration that treaties become the supreme law of the land. Consequently, the NFTC feared, the clause might transfer to the Executive Branch of the Government some of the reserve powers of Congress. The NFTC warned that the phrase binding the United States "to take such measures as it deems appropriate with a view to eliminating such harmful effects" might be construed as an enlargement of the powers of the Executive Branch, committing this country to eliminate "harmftul effects" from restrictive business practices whether or not such practices in a particular case were in violation of existing U.S. antitrust laws. ${ }^{26}$ The NFTC suggested that the language be revised explicitly to obligate the United States to take only those steps authorized by appropriate legislation of Congress.

The State Department acted promptly to quash this construction of its treaty. In a memorandum to the Foreign Relations Committee, the Department pointed out that the Restrictive Business Practices Clause was designed to enlist the cooperation of foreign governments in the efforts of the United States to reduce the adverse effects of cartels and other restrictive practices on international trade.

It will be observed that the clause is not self-executing, and it is also cautiously worded otherwise. The commitments are (1) to consult, i.e., to hold discussions, and (2) to take such action as each party deems appropriate, in its own discretion and in its own way, with a view to eliminating the harmful effects of defined practices on international trade. While the holding of consultations would be an executive function, any action that the United States might see fit to take would be the normal combination of congressional, executive, and judicial action that exists apart from the treaty. The clause has, furthermore, been drafted in such manner as to avoid conflict with the Webb-Pomerene Act and the other enactments which represent exceptions to the basic antitrust law of the United States.

26. Hearing before a Subcommittee of the Senate Committee on Foreign Relations on Treaties of Friendship, Commerce, and Navigation between the U.S. and Colombia, Israel, Ethiopia, Italy, Denmark, and Greece, S. ExEcs. M \& R, 82d Cong., 1st Sess., S. Execs. F, H, I, J, 82d Cong., 2d Sess. 23-25 (1952). 
The clause is not regarded as creating new substantive antitrust law or new procedures of antitrust enforcement in the United States.

It may be stated categorically that the restrictive business practices clause is not in any way designed to enhance executive power or to alter established congressional-executive-judicial relationships in the formulation and execution of antitrust policy. In the State Department's view, the Executive would be bound, in carrying out the clause, to proceed in conformity with statutes duly enacted by the Congress ; and there is no intent to authorize the contrary. A proviso spelling out the internal processes by which the United States acts is therefore unnecessary; it would also appear to be inappropriate in an international instrument, since it is not the concern of a foreign government. ${ }^{27}$

Due to the press of other business, the Senate committee did not act in 1952 on these pending commercial treaties.

When a special Senate Foreign Relations subcommittee met in 1953 to discuss commercial treaties, it went over the same ground once more with the representative of the State Department, who assured Senator Hickenlooper and the committee that the Restrictive Business Practices Clause would convey no legislative authority to the Executive Branch. ${ }^{28}$ When the committee reported the treaties favorably to the Senate, it specifically noted the objection of the National Foreign Trade Council to the restrictive business practices provisions. After citing the State Department's 1952 memorandum on the subject, the committee report stated:

The committee in giving its advice and consent to the treaties with restrictive business practices clauses which contain an undertaking on the part of the United States to take measures it deems appropriate to eliminate restrictive practices, or other similar language, does so with the clear understanding that this does not confer authority upon the Executive to take steps in this respect not heretofore or hereafter authorized by Congress. ${ }^{20}$

With this explanation before it, the Senate gave its advice and consent to the ratification of four commercial treaties containing the Clause. ${ }^{30}$

In 1955 a new Treaty of Friendship, Commerce and Navigation with the Federal Republic of Germany was presented to the Senate. It contained the

27. Id. at 29.

28. Hearing before the Subcommittee of the Senate Committee on Foreign Relations on Tratics of Friendship, Commerce, and Navigation with Israel, Ethiopia, Italy, Denmark, Greece, Finland, Germany, and Japan, S. Exec. R, 82d Cong., 1st Sess., S. Exec. F, H, I, J, 82d Cong., 2d Sess., S. Execs. C, N, O, 83d Cong., 1st Sess. 20-21 (July 13, 1953).

29. S. Exec. Rep. No. 5, 83d Cong., 1st Sess. 7 (1953). This assurance by the Department of State obviated any need for a specific reservation in the clause. See discussion in ABA, Report of the Comm. on Int'l Trade Regulation, Section of Int'l and Comparative Law, Impact of Antitrust Laws on Foreign Trade, 10-11 (Aug. 6, 1953).

30. 99 CoNG. REc. 9316-17 (1953). Three of these treaties have entered into force: those with Israel, Greece and Japan; the fourth, with Denmark, has not. 
standard Restrictive Business Practices Clause. Again the National Foreign Trade Council objected, this time on the ground that the provision might give Germany the right to demand enforcement of American antitrust laws against Americans. The NFTC also suggested that the treaty provision echoed the rejected (Havana Charter) proposal to create a United Nations control agency to supervise the enforcement by the United States of its antitrust laws against American nationals, and to supervise the enforcement of the relatively ineffective or nonexistent laws of other countries against their nationals. ${ }^{31}$

The Senate Foreign Relations Committee, after noting NFTC's objection, stated in its report:

Attention was also given to the suggestion that article XVIII(1) might be construed as authorizing the German Government to demand enforcement of American law against Americans in so far as that law concerns antitrust legislation even though there might be no similar legislation in existence in Germany. The Committee understands this provision to be reciprocal in nature and that it does not give either the German or the United States Governments any right to insist that measures referred to in this article are to be enforced on a unilateral basis. ${ }^{32}$

The meaning of "reciprocal in nature" is unclear. Perhaps the Committee intended that Germany would only be entitled to request, rather than require, enforcement of the American antitrust laws against domestic American firms. Possibly the Committee meant that Germany could request enforcement of our antitrust laws against our citizens only if we had the right to request enforcement of German antitrust laws against Germans, and similar German laws in fact existed..$^{33}$ Whatever the language meant, the Senate ratified the Treaty.

Seven commercial treaties negotiated since 1945 have not yet come into force. In this class are Treaties of Friendship and Commerce with Colombia, ${ }^{34}$ Denmark, ${ }^{35}$ Haiti, ${ }^{36}$ Uruguay, ${ }^{37}$ and Pakistan, ${ }^{38}$ a supplemental commercial

31. S. Exec. Rep. No. 10, 84th Cong., 1st Sess. 10 (1955).

32. Id. at 3. See also note 17 supra for the variant language employed in this treaty to underscore the Foreign Relations Committee's statement.

33. A German antitrust law in fact was passed two years later, Law Against Restraints of Competition of July 27, 1957, effective Jan. 1, 1958, translated and reprinted in WorLb Trade Information Service, U.S. Dep't of Commerce, No. 58-1, pt. 1 (1958).

34. Treaty With Colombia of Friendship, Commerce, and Navigation, Apr. 26, 1951, S. ExEc. M, 82d Cong., 1st Sess. (1951).

35. Treaty With Denmark of Friendship, Commerce, and Navigation, Oct. 1, 1951, S. ExEc. I, 82d Cong., 2d Sess. (1952).

36. Treaty With Haiti of Friendship, Commerce, and Navigation, March 8, 1955,

S. Exec. H, 84th Cong., 1st Sess. (1955).

37. Treaty Wtih Uruguay of Friendship, Commerce, and Economic Development, Nov. 23, 1949, S. ExEc. D, 81st Cong., 2d Sess. (1950). A protocol supplementing this treaty was signed at Montevideo, May 19, 1955.

38. Treaty With Pakistan of Friendship and Commerce, Nov. 12, 1959, S. ExEc. F, 86th Cong., 2d Sess. (1960). 
Agreement with Italy, ${ }^{30}$ and a Convention of Establishment with France. ${ }^{40}$ The United States Senate, during its postconvention session on August 17, 1960, gave its advice and consent to the ratification of the Treaty with Pakistan and the Convention with France. ${ }^{41}$ Both agreements contain the Restrictive Business Practices Clause, although that with France is somewhat watered down. ${ }^{42}$ The clause is also included in the postwar treaties negotiated with Colombia, Denmark, and Uruguay, but it is not clear that these treaties will ever come into force.

Thus, the Restrictive Business Practices Clause currently appears in eight bilateral treaties in force, and in two more on the verge of becoming effective. It may become even more broadly applicable as additional treaties are negotiated.

\section{The Treaty Clause as Construed in United States Courts}

In two cases, federal courts have been asked to throw out antitrust charges because of the existence of the Restrictive Business Practices Clause.

The first case, United States $v$. R. P. Oldham Co., ${ }^{43}$ was a criminal action charging a conspiracy in restraint of American commerce brought under section 1 of the Sherman Act and section 73 of the Wilson Tariff Act. The indictment named five United States corporations importing Japanese wire nails and an American subsidiary of a Japanese nail export company as defendants, and added several Japanese firms as co-conspirators. The defendants moved to dismiss the indictment, contending that the consultation clause of the United States-Japanese commercial treaty ${ }^{44}$ provided the exclusive remedy available to the United States Government in reaching the antitrust conspiracy. District Judge Murphy would not accept this argument, and denied the motion to dismiss. He found the clause to be permissive, not mandatory or exclusive. Although it was not cited, the legislative history of the treaty clause fully supports this result. As additional support for the dismissal Judge Murphy relied on the American nationality of the defendants,

39. Agreement With Italy Supplementing the Treaty of Friendship, Commerce, and Navigation of 1948, Sept. 26, 1951, S. Exec. H, 82d Cong., 2d Sess. (1952).

40. Convention of Establishment With France, Nov. 25, 1959, S. ExEC. G, 86th Cong., $2 d$ Sess. (1960).

41. 106 CoNG. REc. 15367-76, 15417-18 (daily ed., Aug. 17, 1960). Both agreements were ratified by President Eisenhower on August 29, 1960. 43 Dep't State Bulz. 545 (1960).

42. Article XI:

Each High Contracting Party will take the measures it deems appropriate with a view to preventing commercial practices or arrangments, whether effected by one or more private or public commercial enterprises, which restrain competition, limit access to markets or foster monopolistic control, whenever such practices or arrangements have or might have harmful effects on trade between the two countries.

106 Cong. Rec. 15372 (daily ed., Aug. 17, 1960).

43. 152 F. Supp. 818 (N.D. Cal. 1957).

44. See note 16 supra. 
saying that "certainly the Treaty was not intended to exempt nationals from the sanctions of their own country's laws."45

In the second case, In the Matter of Grand Jury Investigation of the Shipping Industry, ${ }^{46}$ the same clause was invoked at an earlier stage of a proceeding. The Justice Department-under prodding by a congressional committee-initiated in late 1959 an investigation of possible law violations in the ocean shipping industry. A grand jury was convened in the District of Columbia. Over 150 respondents were directed to produce documents. Violations of the antitrust laws and of the Shipping Act were suspected.

Six Japanese shipping lines moved to quash the subpoenas duces tecum on the ground that forced production of documents would violate the clause of the commercial treaty between the United States and Japan. ${ }^{47}$ District Judge Walsh refused to grant the motion, holding (as in the Oldham case) that the Restrictive Business Practices Clause is neither a mandatory nor an exclusive remedy. Forced production of documents located in the United States does not violate the clause, he held, even though no consultation had preceded the commencement of the investigation. However the judge reserved his opinion. as to the need to produce documents located abroad, in view of a mass of protests from foreign Governments whose lines would be affected.

Although official protests to the production of documents of foreign shipping lines were made by ten interested Governments, only one nation actually invoked the Restrictive Business Practices Clause of its commercial treaty with the United States. In a note to the American Secretary of State, which was transmitted to the court, Italy declared:

The Italian Embassy submits that, with respect to matters such as those apparently involved in the instant proceedings, proper machinery is set forth in Article XVIII of the Treaty of Friendship, Commerce and Navigation existing between the United States and Italy, and both high contracting parties should take recourse, in all instances, to the same.

... If the United States wishes consultations regarding issues actually contemplated by the instant proceedings, the Italian Government would be willing to meet such request pursuant to and in the spirit of Article XVIII of the existing treaty. 48

The Department of State replied to the Italian protest note in an aide-memoire, attaching a memorandum by the Department of Justice dealing generally with the right of production of documents in grand jury investigations. However neither the aide-memoire nor the legal memorandum so much as mentioned the treaty clause cited by the Italian Government.

Judge Walsh ignored Italy's claim in his opinion, no doubt because the Italian lines, constituting several of the actual parties to the suit, did not specify the

45. 152 F. Supp. at 823 .

46. 1960 Trade Cas. T 69746 (D.D.C. 1960).

47. See note 16 supra.

48. Note in docket file Misc. 5-60, D.D.C., March 5, 1960. 
clause as a technical ground for their motions to quash the subpoenas. In his Shipping Industry opinion, Judge Walsh did mention, without elaboration, that the protest of the Ambassador of Japan did not cite the Restrictive Business Practices Clause of the United States-Japanese commercial treaty. The court might well have been more troubled had the official protest itself, as well as the motions to quash of the Japanese lines, specifically relied on the consultative clause. If this had been done, production under the subpoena could well have been delayed until full and serious consultation had been completed. Such a course would have satisfied the obligations of the treaty, without slighting the power of the United States legislation.

The courts in these two cases re-emphasize the point made in the course of congressional hearings on the commercial treaty program : the Restrictive Business Practices Clause is not "new law" overriding or conflicting with American antitrust legislation. Rather the clause should be a tranquilizing agent to which nations can turn to encourage free international intercourse. But how effective has the clause been in this regard?

\section{Interagency Discussion of International Antirust Disputes}

Let us examine the mechanics for establishing a position within the United States Government when an antitrust problem arises having international impact. After all, the heart of the question lies in the use prior to litigation of the consultative procedure suggested by the treaty clause.

Although responsibility for effective enforcement of federal antitrust laws rest in part with the Federal Trade Commission, in part with other agencies, ${ }^{49}$ and even with private parties, it is principally the Department of Justice which is concerned with problems of extraterritorial enforcement of the Sherman Act. A curtain of secrecy usually shields the process by which the Justice Department's Antitrust Division decides whether to prosecute or withhold prosecution in the case of international business arrangements which might violate United States laws. However a hint occasionally appears as to how it is done.

Apparently as a practical matter the Departments of State and Justice work closely together to develop solutions in antitrust cases which have foreign policy implications. Recent examples include the Swiss Watch, the Oil Cartel, and the

49. Among other agencies having some responsibility for enforcement of federal antitrust laws in international trade are these: the International Cooperation Administration which reviews applications for an investment guaranty from the antitrust standpoint by submitting these agreements for review to the business practices and technology staff of the Department of State, and considers the effect on United States foreign trade of any restrictive provisions. Hearings pursuant to S. Res. 61 Before the Subcommittee on Antitrust and Monopoly of the Senate Committee on the Judiciary, 84th Cong., 1st Sess., pt. 4, at 1826-29 (1955). The Federal Maritime Board reviews shipping conference agreements in foreign trade, and approved agreements are exempted from the antitrust laws under certain conditions. 39 Stat. 733 (1916), as amended, 46 U.S.C. $\$ 814$ (1958). See generally Brewster, Antitrust and American Business Abroad 414-30 (1958); Fugate, Foreign Coaramerce and the Antitrust Laws 294-300 (1958). 
United Fruit cases. ${ }^{50}$ This cooperative effort has been so regularized that the Straus Report in 1959 stated, without qualification,

The Department of Justice in recent years has not taken any action involving foreign relations without prior consultation with the Department of State. ${ }^{.1}$

The apparent closeness of this working relationship between the two departments may, however, be open to question. The 1955 Report of the Attorney General's National Committee to Study the Antitrust Laws asserted that a pressing need existed at that time for advance consultation between the Department of Justice and affected United States Government agencies concerning projected antitrust proceedings in the foreign field. ${ }^{52}$

More often than not, several other United States Government agencies will also have an interest in antitrust proceedings in the international field. Certainly these agencies frequently may be involved: the International Cooperation Administration, Department of Defense, Office of Defense Mobilization, Department of Commerce, Treasury, the Federal Trade Commission, and the Tariff Commission.

Regular consultation by the Justice Department with other interested agencies, before commencing a broad investigation or bringing any antitrust proceeding in the international field, would undoubtedly result in a more accurate assessment of possible damage to America's international position. ${ }^{53}$ By considering the economic, legal and political situation prevailing in foreign countries before deciding whether to institute antitrust proceedings, the Executive Branch should be able to avoid any unnecessary strains on our foreign relations which might follow from improper timing and handling of antitrust prosecutions. Final responsiblity for evaluation of the political questions should not rest with

50. Hearings, supra note 49, at 1846, 1848 (statement of Deputy Assistant Secretary of State Kalijarvi).

51. Straus, Expanding Private Investment for Free World Economic Grozwth, DEP'T of State 30 (1959). This report recommends that the Department of State always be consulted in advance antitrust clearance cases involving the interest of a foreign government or a possible conflict with foreign la $\psi$. Id. at 31 . The interesting comments of the Department of Justice on this recommendation may be found in letters to Sen. Jacob K. Javits dated June 17, 1959, and Dec. 9, 1959, printed in 106 CoNG. Rec. 5762-63 (daily ed., March 22, 1960).

52. 'Atr'y Gen. Nat'z Comm. Antitrust Rep. $97-98$ (1955). This recommendation was rejected as "inadequate" by the special committee report of the Assoctation of THE Bar of the City of New York, National Security and Foreign Policy in the Application of American Antitrust Laws to Commerce with Foreign Nations 25 -26 (1957). The recommendation was praised by the Department of State soon after its appearance. Hearings, supra note 49, at 698-99; Hearings before the Antitrust Subcommittee of the House Committee on the Iudiciary, "Current Antitrust Problems," 84th Cong., 1st Sess., pt. II, at 698-99 (1955).

53. See BREwSTER, op. cit. supra note 49 , at $418-40,444-45$. In the same way, judges in antitrust litigation must weigh the possible conflict of proposed relief with foreign laws, or with other possibly-conflicting U.S. legislative objectives. 
the prosecutor, the Department of Justice. Only the President can exercise the responsiblity for final decision. ${ }^{54}$

\section{Evaluation of the Effectiveness of the Restrictive Business Practices Clause}

\section{Preventing Intergovernmental Friction}

In connection with antitrust litigation in United States courts, bilateral consultation with other interested nations is entirely practical. The former Legal Adviser to the Department of State, Loftus E. Becker, recently discussed the role of that Department in attempting to resolve foreign policy problems arising in the administration of American antitrust laws. He declared,

I believe that the Department of State could do more in the way of affirmative consultation with the foreign governments concerned, with the view of obtaining agreement that specific practices or arrangements are, or are not, contrary to our mutual interests. We would not, of course, be successful in reaching intergovernmental agreement in every such instance, as the Swiss Watch case demonstrates. But the fact that the foreign government in question had been consulted in advance would tend to lessen the violence of its reaction to enforcement of our law. Moreover, through such consultation, both the Department of State, and through it, the Department of Justice would be in a better position to receive and evaluate facts and arguments as to why the particular arrangement or activity should not be proceeded against under our law. I have no doubt that if this were done in more cases than it is done at present, there would be instances in which the two Departments would be thus persuaded by the foreign government, although they might not have been so persuaded had the same arguments been made by attorneys representing private litigants. ${ }^{\mathbf{5 5}}$

But it is essential that intergovernmental consultations take place before the antitrust proceeding is brought. Examples are discouragingly many where consultations were forced upon the United States by miffed nations who learned about a new lawsuit via press service teletype. ${ }^{56}$ For example, in late

54. See National Security and Foreign Policy, supra note 52, at 26-29.

55. Becker, The Antitrust Law and Relations with Foreign Nations, in N.Y. StaTe Bar Ass'n, Section on Antrtrust law, How To Comply With The Clayton Act 51,59 (1959). Similar suggestions for more frequent bilateral consultations between governments have been made recently. See Brewster, Remarks on the Extraterritorial Application of Federal Antitrust Lazes, id. at 63, 67; Kahn-Freund, Extraterritorial Application of Antitrust Laws, 1957 London Proceedings, ABA, SECTron of INT'L AND Comp. LAw, 33, at 42 (19); Timberg, Remarks on Extraterritorial Enforcement of the Sherman Act, id. 51, at 54.

56. Consultations in the Oil Cartel case resulted from strong protests received by the State Department after the Justice Department instituted the litigation. Arabian states, the United Kingdom, and France objected. Hearings, supra note 52, at 695-96. Other recent examples of foreign government protests are noted-for differing reasons- in G. W. Haight, Antitrust Lazes and the Territorial Principle, 11 VAND. L. Rev. 27, 33-34 (1957); Timberg, Conflict and Growth in the International and Comparative Law of Antitrust, in 4 ABA, Section of Int'l and Comp. Law Bull. July, 1960, p. 20. 
1958 the Department of Justice filed a complaint in a New York federal court against General Electric, Westinghouse, and N. V. Philips for an alleged restraint of United States exports to Canada of radio and TV sets. The means alleged was a Canadian patent pool operated by the Canadian subsidiaries of these and other companies. Within days of the filing of the complaint, the Canadian government roared loudly and publicly in protest at this interference in its internal affairs. ${ }^{57}$ In a statement to the Canadian House of Commons the Canadian Minister of Justice, Mr. E. D. Fulton, remarked that he had told the United States Attorney General that:

If the American Government has any feeling that actions in Canada in this or any other field are counter to American interests, or involve any infringement of arrangements with respect to commerce between our two countries, the proper course for them is not to seek to alter the situation in Canada by means of unilateral action in United States courts, but rather to raise the problem with the Canadian Government and express their views and desires through the usual channels. ${ }^{58}$

The Minister added that both Governments had agreed to commence discussions in the future at an earlier stage of the proceedings. He described this understanding on prior consultation as "a real accomplishment." "50

It now appears to be regular practice to notify the relevant embassy through the State Department before any civil proceeding is instituted. This gives foreign companies concerned an opportunity to discuss the matter with the Department of Justice. But this policy has not been regularly followed in regard to criminal proceedings.

In the course of the Grand Jury Investigation of the Shipping Industry, discussed in the preceding section of this article, an attempt was made to subpoena documents of foreign shipping lines. The State Department promptly received protests from the embassies of Great Britain, Canada, Denmark, France, Germany, Italy, Japan, the Netherlands, Norway, and Sweden. ${ }^{00}$ The State

57. The civil suit was filed Nov. 24, 1958. United States v. General Electric, Civ. 140-157, D.J. Case No. 1424, S.D.N.Y. 1958. The Canadian Government promptly made arrangements to discuss the matter with United States officials. Canadian Hansard, Jan. 19,1959 , p. 25. Talks were held in Washington on Jan. 29, 1959, between the Canadian Minister of Justice and William P. Rogers, U.S. Attorney General, with senior officials of their respective departments present. The Canadian officials made it clear that the decree requested by the Department of Justice "could only be regarded as an infringement of Canadian sovereignty."

58. Statement of the Minister of Justice to the House of Commons, Canadian Hansard, Feb. 3, 1959.

59. Ibid.

60. A typical protest note is that of the Netherlands, dated March 7, 1960, addressed to the Secretary of State. Its text, in part, reads:

These subpoenas refer to the production for use by the Grand Jury of a great variety of documents inside the United States, and also of documents located outside the United States. Furthermore, they not only refer to the activities of shipping companies in the United States, but also to shipping between foreign ports. 
Department and the Department of Justice quickly arranged a meeting with the various interested embassies in Washington. ${ }^{61}$ At the close of the session one foreign delegate said that the meeting was "almost an insult." Another said that it had brought to light "nothing we didn't already know." 62 The protests were submitted to the court in connection with motions to quash the subpoenas. The court held that it had "the power, authority, and jurisdiction to require the production of all the documents called for in all of the subpenas herein involved." But Judge Walsh recognized that the "timely objections" of the embassies should be given the greatest consideration. He dismissed their objections as to documents physically located in this country. However, he significantly ruled that,

.. . with respect to the documents of foreign corporations physically located in foreign countries, it would seem that this investigation would not be impeded if the Court reserved its opinion on the production of those documents at this time. ${ }^{63}$

The protests thus proved effective in deferring the production of documents located abroad.

The Shipping Industry case disclosed the inadequacy of present consultation procedures. While consultation prior to the filing of a civil complaint or a criminal indictment is certainly desirable, intergovernment discussions should really begin prior to the investigative stage. When the enveloping tentacles of a grand jury subpoena reach into dusty files of offices around the world, foreign governments are bound to object to this invasion.

The procedure by the United States District Court would accordingly affect persons and documentation outside the executive power and jurisdiction of the United States.

The Netherlands Government has directed Mr. van Roijen to emphasize that it would lead to serious conflicts of jurisdiction if a Government, with or without transgression of the limits of international law, unilaterally institutes proceedings against foreign companies engaged in activities, essentially falling within the jurisdiction of their home countries.

Furthermore, the activities of the United States District Court are of such a farreaching nature that they may unfavorably affect the interests of harmonious international trade, especially if other States would take counter measures or would feel encouraged by the example of the United States to take similar measures involving documentation outside their jurisdiction.

The Netherlands Ambassador therefore is instructed to express the grave concern of the Netherlands Government about the above mentioned action of the United States District Court which directly involves the interests of Netherlands shipping companies, and to state that the Government would welcome any steps that could be taken to ensure that the subpoenas issued to Netherlands shipping companies be withdrawn.

61. 42 Dep'r State Bull. 501 (1960).

62. 35 Pacific Shipper No. 5, p. 23, March 21, 1960. Compare Prof. Metzger's remarks in Proceedings, American Branch, Int'l Law Assn., 1959-60, May 13, 1960, p. 72-75.

63. In the Matter of Grand Jury Investigation of the Shipping Industry, 1960 Trade Cas. $\Uparrow 69746$ (D.D.C. 1960). 
Failure to use available diplomatic channels for consultation does not benefit the United States. Prior to the Shipping Industry investigation, the Italian Government could easily have been notified under the Restrictive Business Practices Clause of our Treaty. This early discussion might well have avoided the protest note, expedited the actual production of documents located in the United States, and speeded up the resolution of the issues involved. It might have uncovered an alternative solution to the situation bothering the Justice Department-a solution perhaps eliminating the need for an antitrust "big case" completely.

Of course, discussions must be conducted in a climate of accommodation to the varying interests of the sovereign parties involved. But most importantly, the time to talk is before the serious phases of an antitrust investigation are begun.

\section{Removing Trade Barriers}

One of the principal aims of the commercial treaty program of the United States is to obtain foreign government assurance that American business can operate in a foreign country on a basis of true competitive equality with local concerns. Equal opportunity in a wide range of commercial and industrial activities is a basic commitment of these treaties. For example, the American businessman is assured the right to manage his business affairs, to hire workers of his choice on the local labor market, to obtain patent and trademark rights, and to be protected against discriminatory taxation, to the same extent as his local counterpart. American firms are assured the same economic favors received from foreign governments by state-controlled competitors. Where the American's competitor is the foreign nation itself, the treaties provide guaranties of nondiscriminatory treatment in the awarding of government contracts and concessions and in the carrying out of nationalization programs. The American firm is permitted to withdraw its capital and earnings to the extent feasible in light of the foreign exchange position of the country. ${ }^{64}$

Government-guaranteed competitive equality might be nullified if private foreign practices effectively blockade doors opened to American business by the commercial treaty program. An example of private restraints might be an industry-wide agreement not to import a particular item at all, or to import it solely from a designated group of nonlocal sources, which did not include the United States. These foreign restrictive practices might be entirely legal, locally, and quite impossible to prosecute from the United States. Even if prosecution in the United States might be theoretically possible, prosecution

64. The examples cited are only a few of the rights and privileges often conceded to American firms by foreign governments under the commercial treaty program. An excellent description and comparative analysis of the more important treaty provisions in all significant commercial treaties has just been published: UNITED States CouncIL, INTERnational Chamber of Commerce, Rights of Businessugen Agroad under Trade AgreeMaENTS ANd Commarcial. TREaties p. 62 (1960). 
might be wholly impractical because of the ineffectiveness of the remedy, the cost and effort involved, or the intergovernmental conflict to be anticipated. In this situation, a new and creative use for the Restrictive Business Practices Clause becomes apparent.

In this "antitrust" provision, the United States and the foreign government have recognized the basic undesirability of harmful effects on their commerce which might result from business practices which restrain competition, limit access to markets, or foster monopolistic control. The American firm wanting to break into the blockaded foreign market should pounce on this language. It gives the State Department a green light to request negotiations leading to the opportunity for entry by the American firm into the foreign market. Negotiation of this type obviously can not be a one-sided demand by the United States that the foreign industry or government fall into line with our antitrust doctrines. ${ }^{05} \mathrm{We}$ should be prepared to offer clear proof of the existence of the restraint and of its harmful effects upon the commerce between the two countries. In many cases, we will find that national legislation and national business practices requiring trade restraints are indispensable to the economic well-being and development of the individual nation. As relatively noncontroversial examples, trademark and patent monoplies are considered entirely proper trade restraints, around the world. Comity demands that the commercial policies of a foreign nation receive the same respect that the Department of Justice insists be accorded United States antitrust laws. This is particularly so where the language of the Restrictive Business Practices Clause is no more specific than the instruction of most of our antitrust laws.

In contrast, a much more generalized treaty provision has been proposed as another legal stepping stone for intergovernmental consultation on barriers in international commerce. During the summer of 1959, Norwegian experts suggested that article XXIII, paragraph I, of the General Agreement on Tariffs and Trade (GATT) be applied to restrictive business practices. The provision reads :

If any contracting party should consider that any benefit accruing to it directly or indirectly under this Agreement is being nullified or impaired or that the attainment of any objective of the Agreement is being impeded as the result of (a) the failure of another contracting party to carry out its obligations under this Agreement, or (b) the application by another contracting party of any measure, whether or not it conflicts with the provisions of this Agreement, or (c) the existence of any other situation, the contracting party may, with a view to the satisfactory adjustment of the matter, make written representations or proposals to the other contracting party or parties which it considers to be concerned. Any con-

65. Hearings, supra note 52, at 684-99; Hearings, supra note 49, 1839-48; Hearings Bcfore the House Select Committee on Small Business, 85th Cong., 1st Sess., pt. II, at 388-401 (1957) (testimony of Assistant Secretary of State Kalijarvi); see OTтo, Tre HuMAN ENTERPRISE 146, 148-49 (1940). 
tracting party thus approached shall give sympathetic consideration to the representations or proposals made to it. ${ }^{66}$

In addition, article XXII of GATT provides that the contracting parties shall accord "sympathetic consideration" to any representations made by other contracting parties regarding any matter affecting the operation of the Agreement. These two GATT provisions are essentially catchall in nature, written without thought of antitrust objectives. By giving a protesting government a peg to hang its protest on, they perhaps are useful technical devices. But their vague, generalized language is not nearly as satisfactory for freeing international trade of unnecessary business restraints as the Restrictive Business Practices Clause. ${ }^{67}$

This more active use of the clause as a means of promoting international trade requires particular care in its application. It goes beyond the "tranquilizing" function, and might itself become a disrupter of foreign tranquility. The Department of Justice recently declared that American companies investing abroad may find that, in order to enter foreign trade, they are required to enter into arrangements which might violate the Sherman Act. The Department suggested that the Restrictive Business Practices Clause be involked by the United States in order to negotiate elimination of restraints in particular cases. ${ }^{68}$ This position, not publicly supported by the Department of State, is based upon inducing the interested foreign government to back down and to "eliminate restraints in particular cases." The nature of the arrangements referred to were not made clear. Joint ventures with local firms are affirmatively encouraged by United States policy. Local price fixing in foreign markets, with very indirect effects on United States foreign commerce, would hardly be a restraint warranting bilateral governmental negotiations. But if an American company investing abroad were forced to agree not to import from the United States, and not export to the United States from its foreign base, there might well be a case for invoking the clause.

Let us therefore make clear that the object of American negotiations would not be a revision of the foreign nation's laws to conform with ours. At most it would be a lifting of the specific restraints having harmful effects on the two countries' commerce in the particular situation. Case-by-case discussion and appropriate individualized action are all that are called for by the clause. They are all that are needed, as a practical matter.

66. Other multinational approaches are suggested from time to time. See S. Con. Res. 85, 86th Cong., 2d Sess., 106 Cong. REc. 1709 (daily ed., Feb. 3, 1960).

67. 61 Stat. (5), (6), T.I.A.S. No. 1700 (1947).

68. Daily Report for Executives, February 11, 1960, pp. A-4 \& A-5. This attitude is repeated by the acting head of the antitrust division, Robert $A$. Bicks, in a letter to Sen. Jacob K. Javits, dated June 17, 1959 :

We believe that intergovernmental discussion may be very helpful in dealing with the problem of business compulsion upon an American company in a foreign country whether exerted directly or indirectly by a foreign government or by a cartelized industry.

106 Cong. Rec. 5762-63 (daily ed., March 22, 1960). 


\section{Conclusion}

The present period in American history would seem to be one in which essentially domestic policies such as antitrust should be required to serve the broad national interest in foreign relations. Imaginative use of the Restrictive Business Practices Clause may yet become a valuable link between these two important American policies. The clause can serve as a soothing agent prior to deciding to institute antitrust proceedings against foreign nationals in the United States. It may also lubricate the channels of international commerce when they become stuck by trade restraints. Consultation between governments is always preferable to unilateral litigation in the courts of one of the affected nations. 


\section{THE YALE LAW JOURNAL}

\section{Robert E. Hudec \\ Editor-in-Chief}

NeAle M. Albert

LAWRENCE G. GOODMAN

David M. TrubeK

JERE A. Young

Note \& Comment Editors

Hershel Y. Allerhand

Charles S. Battles

Joseph S. Borus

Thomas B. Bracken

Carroll W. Brewster

Alan M. Dershowitz

Jan Deutsce

\author{
HARRISON J. GoLDIN \\ Article \& Book \\ Review Editor \\ SidNEY M. WoLINSKY \\ Topics \& Case \\ Editor
}

Peter R. TAft

Managing Editor

Grorge B. Driesen Benjamin S. DuVAI, Jr. JAMES O. FREEDMAN DaVtd I. GoldblatT

David C. Greer

Arthur P. JAcobs

ROBERT A. JOHNSON

LawRENCE P. KLAMON

\author{
ZANE KLEIN \\ Charles E. Lewis \\ JAMES L. MTtCHELL \\ Stoddard D. Platt \\ DAVID A. RoseN \\ STDNEY G. SALtz \\ AdAM WaLINSKY
}

Marie McManon

Business Secretary

\section{CONTRIBUTORS TO THIS ISSUE}

CLYdE W. Summers. B.S. 1939, J.D. 1942, University of Illinois; LL.M. 1946, Columbia University. Professor of Law, Yale University.

Josepr Goldstein. A.B. 1943, Dartmouth College; Ph.D. 1950, London School of Economics; LL.B. 1952, Yale University. Professor of Law, Yale University.

JAY KATz. B.A. 1944, University of Vermont; M.D. 1949, Harvard University. Associate Professor of Law, Associate Clinical Professor of Psychiatry, Yale University.

JAMES T. HAIGHT. B.A., LL.B. 1952, University of Wisconsin. Member of the United States Supreme Court, District of Columbia, Wisconsin, and Ohio Bars. Attorney, Akron, Ohio. 